
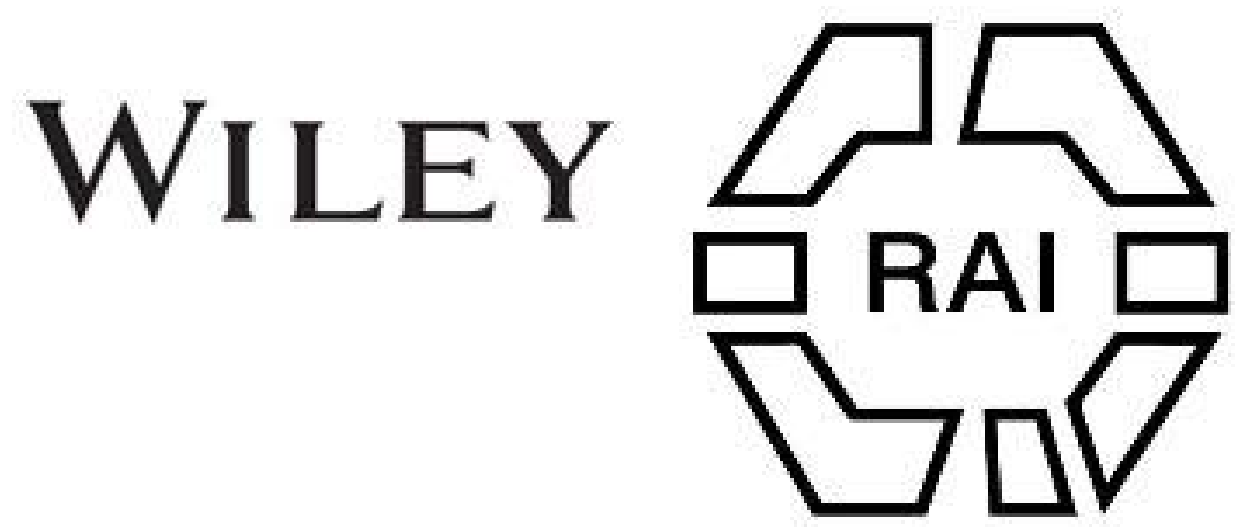

\title{
71. A Revolutionary Theory of Social Anthropology.
} Author(s): Richard C. Temple

Source: Man, Vol. 22 (Aug., 1922), pp. 121-127

Published by: Royal Anthropological Institute of Great Britain and Ireland Stable URL: http://www.jstor.org/stable/2840819

Accessed: 25-06-2016 13:13 UTC

Your use of the JSTOR archive indicates your acceptance of the Terms \& Conditions of Use, available at

http://about.jstor.org/terms

JSTOR is a not-for-profit service that helps scholars, researchers, and students discover, use, and build upon a wide range of content in a trusted digital archive. We use information technology and tools to increase productivity and facilitate new forms of scholarship. For more information about JSTOR, please contact support@jstor.org.

Wiley, Royal Anthropological Institute of Great Britain and Ireland are collaborating with JSTOR to digitize, preserve and extend access to Man 
Social Anthropology.

A remarkable book on the Andaman Islanders, by way of a study in social anthropology, has just been brought out by Mr. A. R. Brown.* It is divided into fairly equal halves, and consists of observations on the Andamanese made on the spot, and of the interpretation thereof. The first part is marred, firstly, by too much stress being laid on the value of the author's own observations and too little on that of his predecessors, especially of so meticulously accurate a recorder as Mr. E. H. Man, who had exceptional chances of observing, spread over a long series of years. Indeed, Mr. Brown seems on occasion to go out of his way to disagree with the results of his predecessors, sometimes on quite minor points, even when they have been, like himself, students of experience, but with better opportunities for observation. Secondly, the book is marred by the adoption of an Eastern European system of transcription for the languages, in supersession of the now long established system devised by so very competent an authority on the recording of human speech on paper as the late Mr. A. J. Ellis. This has had the result of giving words and terms familiar to students of the Andamanese new and puzzling forms, and I may say. as one accustomed to both systems, that Mr. Ellis's is far the more accurate and useful of the two, and much the most intelligible to English readers.

However this may be, the valuable part of the book to this Institute is Mr. Brown's interpretation of his observations. It is in fact an exposition of a new theory of social anthropology, which is explained and examined at great length from many points of view. The book, therefore, is worthy of the most serious consideration by anthropologists.

Mr. Brown's interpretation of Andamanese customs and beliefs, both ceremonial and those connected with myths and legends, aims at supplying "the most urgent need of ethnology at the present time," viz., " a series of investigations in which the observation and the analysis and interpretation of the institutions of some one primitive people are carried on together by the ethnologist working in the field." Passing on to the practice of this general principle, Mr. Brown observes: "The sound rule of method is to formulate clearly and explicitly the working hypothesis on which the interpretation is based." He then discusses the hypotheses previously in vogue : e.g., Tylor's and Frazer's views based on the supposition that the beliefs of savage peoples are due "to attempts on the part of primitive man to explain to himself the phenomena of life and nature." Max Müller's explanation of "the beliefs of primitive man as being due to emotions of surprise and terror." Marrett's view that they are due " to awe and wonder." McDougall's method of using Frazer's and Max Müller's hypotheses "together, one being used to explain some primitive beliefs and the other to explain others." After these statements Mr. Brown is himself again, for these authorities are mentioned " not in order to criticise them, but in order to contrast them with the hypothesis to be formulated" in his book.

All this is to say that we are now confronted with a new and independent theory, which is explained and applied in detail for some 180 pages. This being so, it is worth while examining it, so far as one can in the small space available in a scientific journal. Let us have, in the first place, Mr. Brown's own statement of the new hypothesis (pp. 233-4) : "(1) A society depends for its existence on the presence in " the minds of its members of a certain system of sentiments (organised systems of " emotional tendencies centred about some object) by which the conduct of the " individual is regulated in conformity with the needs of the society. (2) Every

* "The Andaman Isianders, a Study in Social Anthropology," by A. R. Brown, M.A., pp. $x \&$ 504. Cambridge University Press, 1922. 
" feature of the social system itself and every event or object that in any way affects

" the well-being or cohesion of the society becomes an object of this system of

" sentiments. (3) In human society the sentiments in question are not innate, but

" are developed in the individual by the action of the society upon him. (4) The

" ceremonial customs of a society are a means by which the sentiments in question

" are given collective expression on appropriate occasions. (5) The ceremonial

" (i.e., collective) expression of any sentiment serves both to maintain it at the

" requisite degree of intensity in the mind of the individual and to transmit it from

" one generation to another. Without such expression the sentiments involved " could not exist."

Applying the hypothesis to the ceremonial aspects of customs and beliefs, Mr. Brown briefly sums up the position thus (p. 234): "The social function of the ceremonial customs of the Andaman Islanders is to maintain and transmit from one generation to another the emotional disposition on which the society (as it is constituted) depends for its existence." He then tells us (p. 234) that " an attempt will be made to show that there is a correspondence between the customs and beliefs of the Andamanese and a certain system of social sentiments, and that there is also a correspondence between these sentiments and the manner in which the society is constituted." I am deliberately quoting Mr. Brown's ipsissima verba wherever necessary, as it is only fair to him to give his statements concerning his theory verbatim.

Having thus stated his theory and explained his method of applying it, Mr. Brown draws up a few rules of method for himself, the last of which is as subversive of old and still current procedure and ideas as it well can be. These rules are (pp. 234-5) :-“"(1) In explaining any given custom it is necessary to take into account " the explanation given by the natives themselves. Although these explanations " are not of the same kind as the scientific explanations that are the objects of our " search, yet they are of great importance as data. Like the civilised man of "Western Europe, the savage of the Andamans seeks to rationalise his behaviour."

" (2) The assumption is made that when the same or a similar custom is practised " on different occasions, it has the same or a similar meaning in all of them." (3)

" It is assumed that when different customs are practised together on one and the

" same occasion there is a common element in the customs. This rule is the inverse

" of the last. (4) Any comparison of the Andamanese customs with similar customs " of other races are avoided as being misleading as well as unnecessary."

We now know where we are, and it is obvious that we are confronted with an hypothesis very different from any on which we have, as a rule, been hitherto accustomed to work. It is obvious also that this novel hypothesis is worth careful examination. Let us, therefore, follow Mr. Brown a little further. He begins (p. 235) by considering the Andamanese marriage ceremony in the light of the new theory " as one of the simplest and most easily understood." Mr. Brown observes that "the main feature of it is that the bride and bridegroom are required publicly " to embrace each other," and these are the heads of the explanation of this fact (p. 236) : "Everywhere in human life the embrace is employed as an expression of " such feelings as love, affection, friendship, i.e., of feelings of attachment between " persons. There is no need to enquire into the psycho-physical basis of this " expression. . . . It is sufficient for our purpose to satisfy ourselves that the " embrace in all its forms does always express feelings of one genuine kind."

Mr. Brown then carries his explanation further (pp. 236-7): "The meaning " of the marriage ceremony is readily seen. By marriage the man and woman

" are brought into a special and intimate relation to one another : they are, as we

" say, united. The social union is symbolised or expressed by the physical union

" of the embrace." In this way " the rite has two aspects, according as we regard it 
" from the standpoint of the witnesses or from that of the couple themselves. The

" witnesses, by their presence, give their sanction to the union that is then enacted

" before them. The man who conducts the ceremony is merely the active repre-

" sentative of the community: in what he does or says he acts as a deputy and not

" as a private individual. Thus the ceremony serves to make it clear that the

" marriage is a matter that concerns not only those who are entering into it, but

" the whole community, and its occasional performance serves to keep alive this

" sentiment with regard to marriage in general. The existence of the sentiment is

" shown in the reprobation felt and often expressed at an irregular marriage, in

" which the couple unite without ceremony : such a union showing a contemptuous

" or careless thrusting aside of an important social principle."

Having thus explained the ceremony, and its meaning, Mr. Brown goes on to make the pertinent observation on the wedding gifts (p. 237) that they "are " bestowed upon the young couple as an expression of the general good-will towards

" them. The giving of presents is a common method of expressing friendship in

" the Andamans," and (pp. 237-8) " it would be an insult to refuse a present offered,

" for to do so would be equivalent to rejecting the good-will it represents. At

" marriages the giving is one-sided, no return being expected, for it is an expression,

" not of personal friendship on the part of the givers, but of general social good-will

" and approval. It is for this reason that it is the duty of everybody who is present " to make some gift to the newly-married pair."

Here one can almost hear the man in the street, if he could be got to read this passage, saying :- " How jolly like other people !" and the argument confirms an observation of my own made long ago :- "A savage is, after all, just an ordinary " man." Not only do I heartily agree with Mr. Brown on this matter, but I based (also long ago in 1883) a Theory of Universal Grammar on the observation that the thoughts of all mankind and their expression were but the phenomena of the working of one class of mind-the human. Therefore all the varieties of speech must be governed by one set of general natural laws.

The marriage ceremony leads Mr. Brown to the peace-making ceremony (dance) of the North Andaman (p. 238). The symbolism of this dance, he says, is "at once " obvious to a witness, though not perhaps quite so obvious from the description" on paper. "The dancers are divided into two parties. The actions of the one party " throughout are expressions of their aggressive feelings towards each other." But " on the other side what is expressed may be described as complete passivity"; the dancers, as it were, " humbling themselves before the just wrath of their enemies, " expiate their wrongs. Anger appeased dies down; wrongs expiated are forgiven " and forgotten; the enmity is at an end." The point of the ceremony for the present purpose is clearly that socially it reflects the collective expression of collective tribal emotion.

These two ceremonies-marriage and peace-making-lead to a consideration of the most commonly remarked Andamanese custom of all-that of ceremonial weeping. An Andamanese can always produce tears to order, as it were. Mr. Brown gives (p. 239) the seven principal occasions therefor : (1) at meeting after parting, (2) at peacemaking, (3) at the end of mourning, (4) at death, (5) at the recovery of the bones of the dead from graves, (6) at marriages, (7) at initiation ceremonies. He then explains (p. 239) that " not in any one of the above-mentioned " instances is the weeping simply a spontaneous expression of feeling. It is always " a rite, the proper performance of which is demanded by custom." After going into details at considerable length Mr. Brown arrives at the conclusion (p. 245) that the weeping rite is " the affirmation of a bond of social solidarity between those taking " part in it, and as producing in them a realisation of that bond by arousing the " sentiment of attachment." And then he brings out four points of general 
importance in relation to all these ceremonies,-marriage, peacemaking, weeping,(pp. 245-6) :-“"(1) in every instance the ceremony is the expression of an affective "state of mind shared by two or more parties." . . . "(2) The ceremonies " are not spontaneous expressions of feeling : they are all customary actions to which " the sentiment of obligation attaches, which it is the duty of persons to perform " on certain definite occasions." . . . "(3) In every instance the ceremony is " to be explained by reference to fundamental laws regulating the affective life of " human beings." . . . "(4) Each of the ceremonies serves to renew or to " modify in the minds of those taking part in it some one or more of the social "sentiments."

Mr. Brown next examines the meaning and functions of the dance and has some pertinent notes thereon. He begins by remarking (p. 247) that "the ordinary "Andaman dance may be looked on as a form of play," and then he says : "If an "Andaman Islander is asked why he dances he gives an answer that amounts to " saying that he does so because he enjoys it. Dancing is, therefore, in general a " means of enjoyment." In Mr. Brown's eyes "the Andaman song is an accom" paniment of the dance" (p. 247), and is of quite secondary importance. He winds up his remarks on this subject by saying (p. 252): "the dance produces a " condition in which the unity, harmony and concord of the community are at a " maximum, and in which they are intensely felt by every member. It is to produce " this condition, I would maintain, that is the primary social function of the dance." But on p. 249 in a footnote he remarks that " the psychology of dancing offers a wide " field for study that has as yet, so far as I know, been barely touched." This I present to Sir William Ridgeway for contemplation.

A consideration of the dance leads to the much more complicated question of the dance-costumes, including ornamenting and painting the body, and their symbolism. This subject Mr. Brown tackles boldly and his final remark thereon is characteristic (p. 275): " Of course it is probable that the Andamanese custom of painting the body " after eating, like our own grace before and after meat, with which it is parallel, " tends to become a formality accompanied by little real feeling, but it can be shown, "I believe, that such customs do possess a real value-a real psychological "function-in keeping alive ideas and sentiments that will on occasion play an " important part in influencing conduct." Thus (p. 275) each of these ceremonies " is an action required by custom, the performance of which on appropriate occasions " serves to keep alive in the mind of the individual a certain system of sentiments " necessary for the regulation of conduct in conformity to the needs of the society " as they have been handed down by tradition." . . . It serves " to make " the individual feel the solidarity and unity of the community: all share in " the repast and the common danger, and each man sees on his neighbour [in the "Andamans] the clay with which he himself is daubed."

Mr. Brown then passes on to the social values of food and its getting and consumption, which last is mixed up with initiation ceremonies. A consideration of these leads him to remark (p. 284) that the "Andamanese customs relating to food " are all of them different modes of expressing the social value of foods." $\mathrm{He}$ then dives (pp. 284-5) into the vexed question of "the nature of the dangers that " are supposed to accrue from the eating of food if due precautions are not taken.

" One statement of the natives is that the danger they fear is sickness. Sickness

" of all kinds is believed by the Andamanese to be caused by . . . . the " spirits of the dead :" a remark that leads naturally to a consideration of the Andaman notions of spirits, as evidenced in the custom relating to deaths and burials.

Upon this follows a complicated and instructive argument covering many discursive subjects of great interest, which is worth careful study, but is far too long for more than a mere mention here. The main point of it goes back to the statement 
that customs connected with these subjects (p. 297) are "ritual actions performed " under a sense of obligation and strictly regulated by tradition. They are means " by which the society acts upon its members, compelling them to feel emotions " appropriate to the occasion."

In bringing his argument as to ceremonial customs and beliefs to a conclusion, Mr. Brown argues (p. 324) that it is "evident that the ceremonial customs are the " means by which the society acts upon its individual members and keeps alive in " their minds a certain system of sentiments. Without the ceremonial those " sentiments would not exist, and without them the social organisation in its actual " form could not exist. There is great difficulty, however, in finding a suitable " method of describing these sentiments. In attempting to put into precise words " the vague feelings of the Andaman Islander there is always the danger that we " may attribute to him conceptions that he does not possess. For he is not himself " capable of thinking about his own sentiments." The moral of which consideration is that in diagnosing them for him or similar persons doctors are bound to differmuch more so are students bound to differ : a point that Mr. Brown does not always take sufficiently into his purview.

The thought that must arise in every mind on a perusal of Mr. Brown's pages is that here we have a direct challenge to long accepted ideas as to the correct method of interpreting ceremonial customs and beliefs, in pursuance of which very many books have been written by many enquirers, involving an enormous quantity of labour and thought for the best part of a century. This is, therefore, indeed a revolutionary book, and the skill with which the argument is conducted deserves the fullest consideration of this Institute.

Mr. Brown follows up his argument as to ceremonial by another, extending over some 75 pages, on myths and legends, which cover of course religion, worked out resolutely on the same lines, whereby he seeks (p. 331) "to prove that the tales " that seem merely the products of a somewhat childish fancy are very far indeed " from being merely fanciful and are the means by which the Andamanese express " and systematise their fundamental notions of life and nature and the sentiments " attaching to those notions." Here again I find myself in entire agreement with Mr. Brown, for I have long preached that no custom or belief is in itself silly, but has a history somewhere worth investigating. Mr. Brown's general view here is that (p. 377) " the legends have for their function to express the social values of different " objects,- to express in general the system of social values that is characteristic " of the Andaman social organisation." And in this connection he acutely remarks (p. 379) that "the Andaman Islander has no interest in nature save in so far as it " directly affects social life."

Finally, on the subject of religion Mr. Brown is worth quoting in full (p. 405).

"When we use the term ' religion' we inevitably think first of what we understand

" by that term in civilised society. It is not possible, I believe, to give an exact

" definition which shall retain all the connotations of the word as commonly used

" and which shall at the same time help us in the study of the customs of undeveloped

" societies. The definition of religion that seems to me on the whole most satis-

" factory is that it consists of (1) a belief in a great moral force or power (whether

" personal or not) existing in nature, and (2) an organised relation between man

" and this Higher Power. If this definition be accepted it is clear that the Anda-

" manese have religious beliefs and customs. They do believe in a moral power

" regulating the universe, and they have organised their relations to that power

" by means of some of their simple ceremonies. Yet it does not seem possible to

" draw a sharp dividing line between those beliefs and customs that properly deserve

" to be called religious and others which do not deserve that adjective. It is not

" possible, in the Andamans, to separate a definite entity which we call religion 
" from things that may more appropriately be regarded as art, morality, play, or " social ceremonial." Here Mr. Brown, as I take it, is dealing with the ceremonial side of religion, and then he proceeds apparently to view it from the philosophic side, as to which it is obvious that the ideas of an Andamanese would be of the very haziest. The distinction is important to my mind, and I have long argued that historically the religious customs and beliefs of a people based on the philosophy it has learnt have often an origin totally distinct from that of the customs and beliefs exhibited in its religious ceremonies.

Be this as it may, Mr. Brown goes on (pp. 405-6) : "Nevertheless the purpose " of these two chapters [ceremonies, and myths and legends] has been to explain "the nature and function of Andamanese religion. Amongst the fundamental " conditions that must be fulfilled. if human beings are to live together in society is " the existence of this thing that we call religion, the belief in a great Unseen Power,

" between which and ourselves it must ever be the great concern of life to establish

" and maintain harmony. The Andaman Islander with his somewhat childish

" faith, the Australian black-fellow decorated with paint and feathers impersonating

" his totemic ancestor, the Polynesian sacrificing human victims on the maral of

" his god, the Buddhist following the Holy Eight-staged Path, are all following " in however different ways the same eternal quest." By which remarks Mr. Brown shows himself, however unwittingly, to be a member of a human society with a religious history of its own.

I have thus presented Mr. Brown's theory at some length, and it must now be clear to the reader that if it proves to be generally acceptable, the method of studying primitive peoples will be revolutionised. Hence the space I have devoted to it needs no apology.

As to how long it may take to bring about a revolution two little personal stories in connection with the study of the Andamanese may be to the point. Just 40 years ago (1882) Mr. A. J. Ellis wrote to me, a propos the Andaman and Nicobar languages, urging the necessity of devising a new method of recording the grammar of "savage languages," which should not oblige observers to use the modern European system and terminology based on Latin Grammar, as so much of them was inapplicable. I followed up the idea and produced a "Theory of Universal Grammar," which was subsequently expounded in all sorts of places at every opportunity, including a British Association Meeting at Cambridge. It was often generally agreed to, and also applied by experts, to their minds successfully, to a great variety of tongues, including Latin itself. It was revised and revised again under an altered title, and applied by myself in detail to the very widely different languages of the Andamans and Nicobars. And yet it has remained what it was originally: just a theory unapplied generally. Quite lately I found myself on an authoritative Committee with instructions to bring the Grammar of Indian "Aryan " languages into line with that of the European languages of the same order, and I had meekly to agree, in the general interests of the ordinary teacher and his pupils, to the adoption of a modification of the old Latin terminology and system. Vested interests, even in knowledge, die hard.

The other story is that nine years ago (1913) I propounded a scheme for extending the teaching of Mr. Brown's own subject—applied cultural anthropology. Many were enthusiastic for its application and as many against it. Unfortunately it trod on toes, and, though the proposal was vigorously followed up on every opportunity arising and found lively adherents, its opponents have so far proved too strong. Vested interests in learning and knowledge are as strong as those in commerce, religion, and any other such human subject one might mention. It is human nature, and shall we say it might be instructive if some one will use Mr. Brown's method to examine the point? 
Yet another instance of a theory, worked out at great length by many intelligent workers collecting in co-operation an enormous mass of material on the spot, and yet failing to become generally known and utilised by searchers, is Sir James Campbell's "Spirit Basis of Belief and Custom," as the outcome of information gathered a quarter of a century and more ago in connection with the Census of India of 1891 and the monumental 26 volumes of the Bombay Gazetteer, of which he was the editor and guide. Perhaps Mr. Brown's "Social Basis of Belief and Custom" will have better luck. He has a chance, as the general idea is "in the air": vide Mr. A. M. Hocart's " Common Sense of Myth" in the American Anthropologist, N.S., Vol. 18, p. 307 (1916) and his "Myths in the Making" in Folklore, March, 1922, p. 57.

R. C. TEMPLE.

\section{REVIEWS.}

Europe, Western : Religion.

Murray : Winstanley.

The Witch-Cult in Western Europe: A Study in Anthropology. By Margaret Alice Murray. Oxford: Clarendon Press, 1921. Pp. 303. Price 16s. net.

Tuo Trials for Witchcraft. By Miss M. A. Murray. Reprinted from the Proceedings of the Society of Antiquaries of Scotland. Vol. VIII., Fifth Series. Session 1921-22. Pp. 46-60.

Macheth, King Lear and. Contemporary Hisiory. By Lilian Winstanley. Cambridge University Press. 1922. Pp. 228. Price 15s. net.

In her study of witchcraft, Miss Murray has confined herself to ceremonial; she has not dealt with " operative magic," the spells, charms, and the like employed by witches. Taking the accounts given by the witches themselves at their trials, she deduces from them the character of the god, of the admission ceremonies and of the assemblies, and describes the rites and the organisation, with its inner circle of " covens" of thirteen individuals or multiples of thirteen, by which the cult was carried on. Her attention is directed chiefly to the cult as it existed in these islands ; but for the purposes of elucidation and amplification she quotes freely from the voluminous records of French trials.

As a result of her investigations Miss Murray arrives at the conclusion that the witch-cult was an organised religion, which she would call the Dianic Cult, and that it was a survival of a primitive religion, more or less uniform over the whole of Western Europe, which was superseded by Christianity, but only slowly and at a much later date than is generally believed. The chief element in this religion was the worship of the God incarnate who appeared to his votaries now as a man, now as an animal, and was confused with the devil by Christians. The central feature of the ceremonial was a fertility rite performed at periodical assemblies, and particularly at the quarterly festivals of a pre-solstitial year. That such a primitive cult may have survived does not involve too great an assumption. As was pointed out by Sir Walter Scott, the wholesale conversions of tribes and peoples to Christianity was probably for long nothing more than an empty conformity with the conversion of their chiefs. Miss Murray's analysis of the Christian names of the witches shows that none bore Saxon or Scandinavian names, and lends support to the view that they belonged to families or groups whose traditions extended in unbroken line to pre-Christian times. Further, the confessions of the witches themselves showed that their cult was not a furtive association merely for wrong-doing, but was a "joyous religion," which brought its votaries happiness and for which they were prepared to suffer martyrdom. Originally beneficial and intended to promote fertility, it was only in the popular view that the cult was malevolent, at least until it degenerated into the form in which it appears in later times, when the witch's hand was against every man. 